\title{
GAMETOGENESIS AND REPRODUCTION OF THE MATRINXÃ Brycon orthotaenia (GÜNTHER, 1864) (PISCES: CHARACIDAE) IN THE SÃO FRANCISCO RIVER, MINAS GERAIS, BRAZIL
}

\author{
GONÇALVES, T. L., BAZZOLI, N. and BRITO, M. F. G. \\ Programa de Pós-Graduação em Zoologia de Verterbrados, \\ Pontíficia Universidade Católica de Minas Gerais - PUC Minas, Av. Dom José Gaspar, 500, \\ Coração Eucarístico, Prédio 41, CEP 30535-610, Belo Horizonte, Minas Gerais, Brazil \\ Correspondence to: Nilo Bazzoli, Programa de Pós-Graduação em Zoologia de Verterbrados, \\ Pontíficia Universidade Católica de Minas Gerais - PUC Minas, Av. Dom José Gaspar, 500, Coração Eucarístico, \\ Prédio 41, CEP 30535-610, Belo Horizonte, Minas Gerais, Brazil, e-mail: bazzoli@ pucminas.br \\ Received June 17, 2004 - Accepted August 11, 2004 - Distributed May 31, 2006 \\ (With 17 figures)
}

\begin{abstract}
The gametogenesis and reproduction of the matrinxã, Brycon orthotaenia in the São Francisco river, Pirapora Region, Minas Gerais, were studied from December, 1998 to November, 1999. The matrinxã B. orthotaenia is an endemic species in the São Francisco river basin in Brazil and important for commercial fishing. The size of the $1^{\text {st }}$ gonadal maturation, indicated by the total length of the smallest spent males and spawned female, was 32.0 and $40.5 \mathrm{~cm}$ respectively. Reproduction occurred from October to January, when high frequencies of females and males at an advanced ripening/mature stage and spawned females were found. The short spawning period and histological characteristics of spawned ovaries containing only oocytes in stages of initial development, along with post-ovulatory and atresic follicles, indicated that Brycon orthotaenia presents total spawning.
\end{abstract}

Keywords: teleost fish, oogenesis, spermatogenesis, reproductive cycle.

\section{RESUMO}

Gametogênese e reprodução do matrinxã Brycon orthotaenia (Günther, 1864) (Pisces: Characidae) do rio São Francisco, Minas Gerais

Estudaram-se a gametogênese e a reprodução de Brycon orthotaenia do rio São Francisco, na região de Pirapora, Minas Gerais, no período de dezembro/1998 a novembro/1999. O matrinxã B. orthotaenia é uma espécie endêmica da bacia do rio São Francisco, Brasil e importante na pesca comercial. O tamanho de $1^{\mathrm{a}}$ maturação gonadal, indicado pelo comprimento total do menor macho espermiado e da menor fêmea desovada, foi de 32,0 e 40,5 cm, respectivamente. A reprodução ocorreu de outubro a janeiro, quando observam-se altas freqüências de fêmeas e machos no estádio maturação avançada/maduro e fêmeas desovadas. O curto período de desova e as características histológicas de ovários desovados, contendo somente ovócitos nos estádios iniciais de desenvolvimento ao lado de folículos pós-ovulatórios e atrésicos, indicam que a desova de $B$. orthotaenia é do tipo total.

Palavras-chave: peixe teleósteo, ovogênese, espermatogênese, ciclo reprodutivo.

\section{INTRODUCTION}

Human population growth and an increase in agricultural and industrial activities, as well as dam construction, mineral extraction, deforestation and predatory fishing cause changes in the environment that directly affect fish. As a result of this environment degradation, the São Francisco river, which was one of the main fishing resources in Brazil, is presently a fishery in decline (Godinho \& Godinho, 2003). Taking this into consideration, 
the matrinxã, Brycon orthotaenia (Günther, 1864) known previously as $B$. lundii Reinhardt, 1874 , an endemic species in the São Francisco river basin and important for commercial fishing, reaching $7 \mathrm{~kg}$ of body weight, is threatened with extinction in some regions of the São Francisco basin (Sato, 1999).

The knowledge about different stages of fish gonadal maturation provides important information necessary to prohibit fishing during the reproduction period; allowing the fishery stock to recover (Noble \& Jones, 1993). Establishing the reproduction period and length of gonadal maturation, using microscopic criterion justify implementing fishery legislation more accurately (Bazzoli, 2003).

The present work outlines the stages and size of $1^{\text {st }}$ gonadal maturation, the reproductive period and type of spawning of the matrinxã, B.orthotaenia in the São Francisco river, Pirapora Region, Minas Gerais, Brazil.

\section{MATERIALS AND METHODS}

\section{The fish}

A total of 75 specimens, 55 females and 20 males of the matrinxã $B$. orthotaenia were collected by fishermen using casting and drifting nets between December, 1998 and November, 1999 in the São Francisco river, Pirapora Region (17 ${ }^{\circ} 20^{\prime}$ $45^{\prime \prime} \mathrm{S}$ and $44^{\circ} 56^{\prime} 55^{\prime \prime} \mathrm{W}$ ), state of Minas Gerais, Brazil. Each fish was measured (total and standard length), weighed (body weight) and sexed.

\section{Light microscopy}

Fragments of gonads from all specimens were fixed in Bouin's fluid for 4-12 $\mathrm{h}$ and subjected to routine histological techniques: embedded in paraffin, sectioned at 3 a $5 \mu \mathrm{m}$ and stained with hematoxylin/eosin (HE), in the Ichthyology Laboratory, Graduate Program in Zoology of Vertebrates, Pontifical Catholic University of Minas Gerais.

\section{Stages of gonadal maturation and type of spawning}

Microscopically, the stages of gonadal maturation were determined based on the distribution of oocytes and spermatogenic cells. The type of spawning was identified based on histological characteristics of spawned ovaries as well as frequency distribution of the stages of gonadal maturation (Bazzoli, 2003).

\section{Size of $1^{\text {st }}$ gonadal maturation}

The length of the $1^{\text {st }}$ gonadal maturation was indicated by the total length of the smallest regression male and female.

\section{RESULTS}

\section{Morphology of ovaries and oogenesis}

The ovaries of B. orthotaenia were paired, elongated organs located in the coelomic cavity laterally to the digestive tube, ventrally to the kidneys and ventro-laterally to the gas bladder. The ovaries were attached to the gas bladder through the mesovarium and joined at their caudal ends to form the common ovarian duct, which opened at the urogenital papilla. Macroscopically, the ovaries presented variations in the volume, thickness and color, according to the stages of gonadal maturation. Microscopically, they were wrapped by the tunica albuginea that emits septae to the inside of the organ, forming ovigerous lamellae in which there were oocytes in different development stages.

During oogenesis, primordial germ cells or oogonias (characteristically small, with a vesiculous nucleus, a central nucleolus and scarce cytoplasm) give origin to oocytes, which based on nucleus, cytoplasm and envoltory changes, were classified into four development stages: $\mathrm{O} 1=$ initial perinucleolar, $\mathrm{O} 2=$ advanced perinucleolar, $\mathrm{O} 3=$ previtellogenic and $\mathrm{O} 4=$ vitellogenic (Figs. 1-4).

\section{Morphology of testes and spermatogenesis}

The testes of $B$. orthotaenia were paired, elongated and fusiform organs located in the coelomic cavity laterally to the digestive tube, ventrally to the kidneys and ventro-laterally to the gas bladder. The testes were attached to the gas bladder through the mesorquium and joined at their caudal ends to form the common spermatic duct, which opened at the urogenital papilla, where the spermatozoa leave the body. Microscopically, the testes were wrapped by the tunica albuginea that emits septae to the inside of the organ, forming lobules filled with semniferous tubules. The wall of these tubules was made up of cysts that were 

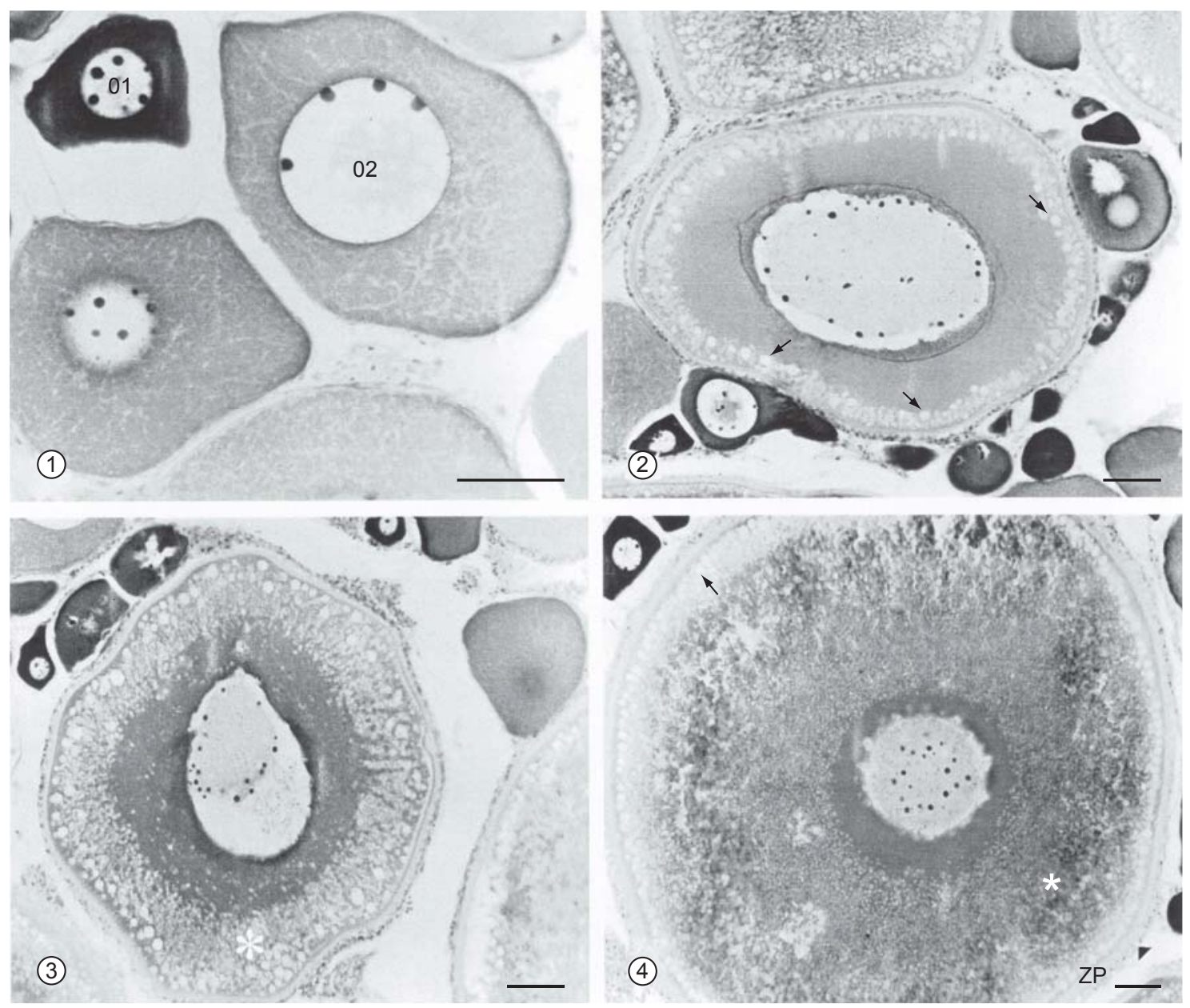

Fig. 1-4 - Oocytes of B. orthotaenia: 1) initial perinucleolar oocyte (O1) containing basophyle cytoplasm and nucleus with various nucleoli and advanced perinucleolar oocyte $(\mathrm{O} 2)$ containing basophyle finely granular cytoplasm and nucleus with nucleoli near the nuclear envoltory; 2) previtellogenic oocyte with characteristic cortical alveoli (arrow); 3) vitellogenic oocyte containing initial deposits of acidophyle yolk globules (asterisk); and 4) vitellogenic oocyte containing cytoplasm filled with yolk globules (asterisk), cortical alveoli in the peripheric ooplasm (arrow), thin zona pellucida (ZP) and cubic follicular cells (arrow head). HE. Scale bars $=50 \mu \mathrm{m}$.

delimited by cytoplasmatic elongations of Sertoli cells. In each cyst, spermatogenic cells in the same development stage were found.

During spermatogenesis, alterations in primordial germ cells or spermatogonias give origin to spermatozoa. Based on the histological characteristics, six types of cells were identified during the spermatogenic development: primary spermatogonia, secondary spermatogonia, primary spermatocytes, secondary spermatocytes, spermatids and spermatozoa (Fig. 11)

\section{Stages of gonadal maturation}

Based on macro and microscopic characteristics of the gonads, the following stages of gonadal maturation were determined: $1=$ resting, $2=$ initial maturation, 3 = advanced maturation/mature and $4=$ regression (Table 1 and Figs. 5-10 and 12-16).

After spawning, post-ovulatory or empty follicles were formed and the vitellogenic oocytes that had not ovulated started the process of absorption or follicular atresia. Post-ovulatory follicles presented lumen and wall made up of 
TABLE 1

Macro and microscopic characteristics of stages of gonadal maturation (SGM) of females and males of Brycon orthotaenia in the São Francisco river, state of Minas Gerais between December, 1998 and November, 1999.

\begin{tabular}{|c|l|l|}
\hline \multirow{2}{*}{ SGM } & \multicolumn{2}{|c|}{ Morphologic characteristics } \\
\cline { 2 - 3 } & \multicolumn{1}{|c|}{ Ovaries } & \multicolumn{1}{c|}{ Testes } \\
\hline 1 & $\begin{array}{l}\text { - Translucent and not very voluminous; } \\
\text { - Presence of O1 and O2. }\end{array}$ & $\begin{array}{l}\text { - Thin and translucent; } \\
\text { Lumen of seminiferous tubules closed and wall } \\
\text { made up of spermatogonias. }\end{array}$ \\
\hline 2 & $\begin{array}{l}\text { - Greenish, voluminous and some oocytes visible } \\
\text { to the naked eye; } \\
\text { - Presence of O1, O2, O3. }\end{array}$ & $\begin{array}{l}\text { - Whitish and voluminous; } \\
\text { - Lumen of seminiferous tubules open with small } \\
\text { quantity of spermatozoa and wall made up of } \\
\text { cysts of all spermatogenic cells. }\end{array}$ \\
\hline 3 & $\begin{array}{l}\text { - Dark greenish to purple, maximum volume and } \\
\text { numerous oocytes visible to the naked eye; } \\
\text { - Presence of O1, O2, O3 and mainly O4. }\end{array}$ & $\begin{array}{l}\text { - Milky-whitish and maximum volume; } \\
\text { - Lumen seminiferous tubules with large quantity } \\
\text { of spermatozoa and acidophyle secretion. }\end{array}$ \\
\hline 4 & $\begin{array}{l}\text { - Flaccid and hemorrhagic, with some oocytes } \\
\text { visible to the naked eye; } \\
\text { Presence of O1, O2, post-ovulatory follicles, in } \\
\text { addition to rare O3 and O4 in follicular atresia. }\end{array}$ & $\begin{array}{l}\text { - Flaccid and hemorrhagic; } \\
\text { Lumen of seminiferous tubules open with } \\
\text { residual spermatozoa and wall made up of } \\
\text { spermatogonias, only. }\end{array}$ \\
\hline
\end{tabular}

$\mathrm{SGM}=$ stages of gonadal maturation, $1=$ resting, $2=$ initial maturation, $3=$ advanced maturation $/$ mature, $4=$ regression for females and spent for males, $\mathrm{O} 1=$ initial perinucleolar, $\mathrm{O} 2=$ advanced perinucleolar, $\mathrm{O} 3$ = previtellogenic and $\mathrm{O} 4=$ vitellogenic.

follicular cells and conjunctive theca, which remained in the ovaries after ovulation (Fig. 9). The atresic follicles were more frequent in regression ovaries and were characterized by cell tugidity, hatching of zona pellucida, yolk liquefaction, nucleus disintegration and absorption of ovule contents by follicular cells (Fig. 10).

\section{Frequency of stages of gonadal maturation and type of spawning}

High frequencies of females in the advanced maturation/mature and regression stages were recorded during October/November and December/ January. Males in the advanced maturation/mature stage occurred only during October/November and December/January, while ones in the regression stage were not captured only during April/May and June/July (Fig. 17).

The short spawning period and histological characteristics of the regression ovaries, containing only initial and advanced perinucleolar oocytes, as well as post-ovulatory and atresic follicles, indicated that $B$. orthotaenia presents total spawning.

\section{Length of $1^{\text {st }}$ gonadal maturation}

The smallest male and female captured in the advanced maturation/mature stage measured 30.0 and $33.5 \mathrm{~cm}$ of total length, respectively. The smallest regression male and female measured 32.0 and $40.5 \mathrm{~cm}$ of total length, respectively (Tables 2 and 3).

\section{DISCUSSION}

In this work, the small number of captured specimens may be related to the fact that $B$. orthotaenia is probably among the endangered species of the São Francisco river (Lins et al., 1997), especially in some regions, such as downstream of the Três Marias storage dam, and upstream of the Sobradinho storage dam to the Atlantic Ocean (Sato, 1999).

The macroscopic morphology of the gonads of $B$. orthotaenia was similar to reports from Zaniboni-Filho (1988) and Romagosa et al. (1999) for Brycon cephalus, an abundant and economically important fish found in the Amazon river basin in Brazil. The morphological changes observed in the nucleus, cytoplasm and oocyte envoltories 


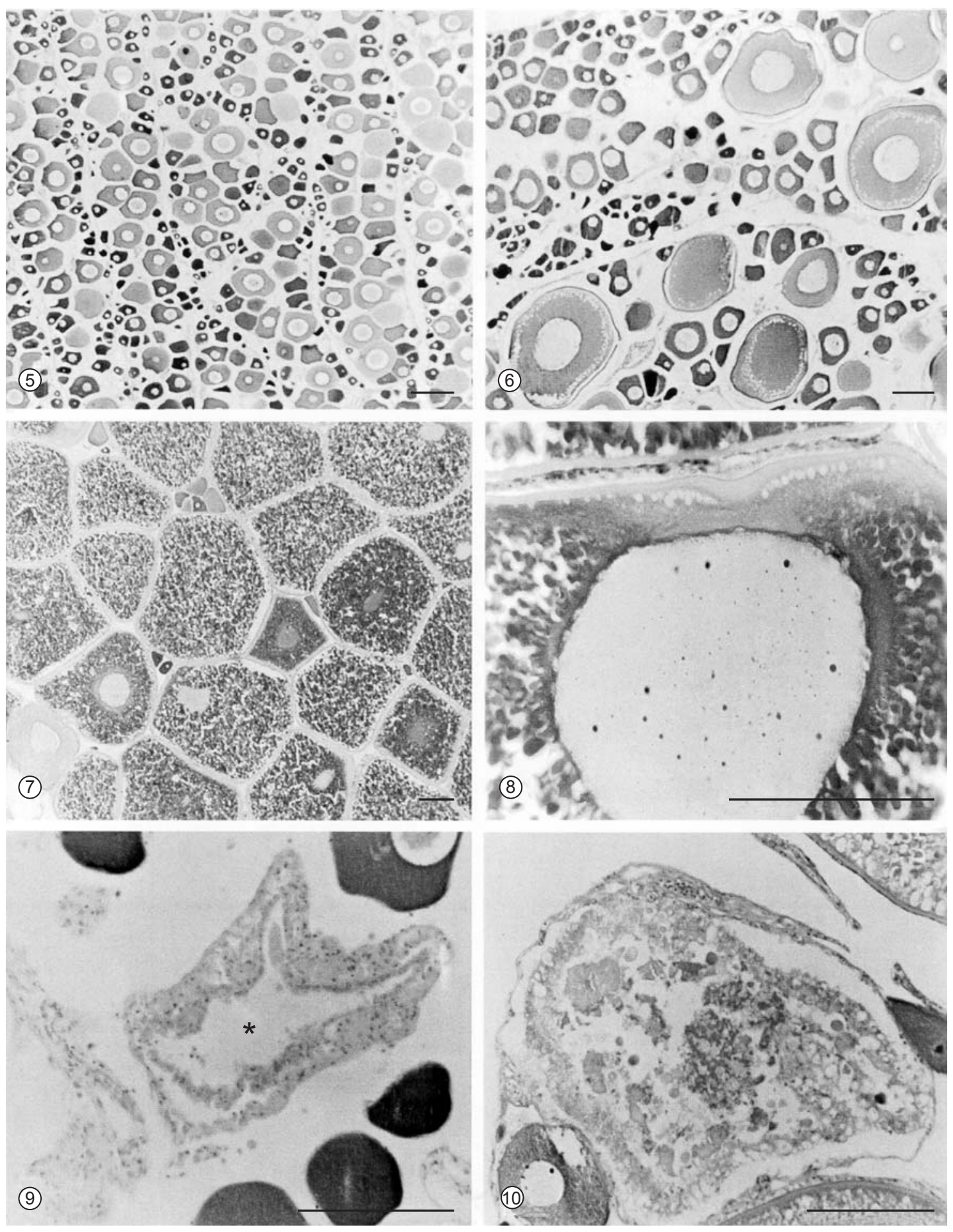

Fig. 5-10 - Ovaries of B. orthotaenia in different stages of maturation: 5) stage 1 or resting; 6) stage 2 or initial maturation; 7) stage 3 or advanced maturation/mature; 8) detail of vitellogenic oocyte with nucleus dislocated to the micropyle in mature ovary; 9) stage 4 or regression with post-ovulatory follicle (asterisc); and 10) detail of follicular atresia in vitellogenic oocyte. HE. Scale bars $=150 \mu \mathrm{m}$. 

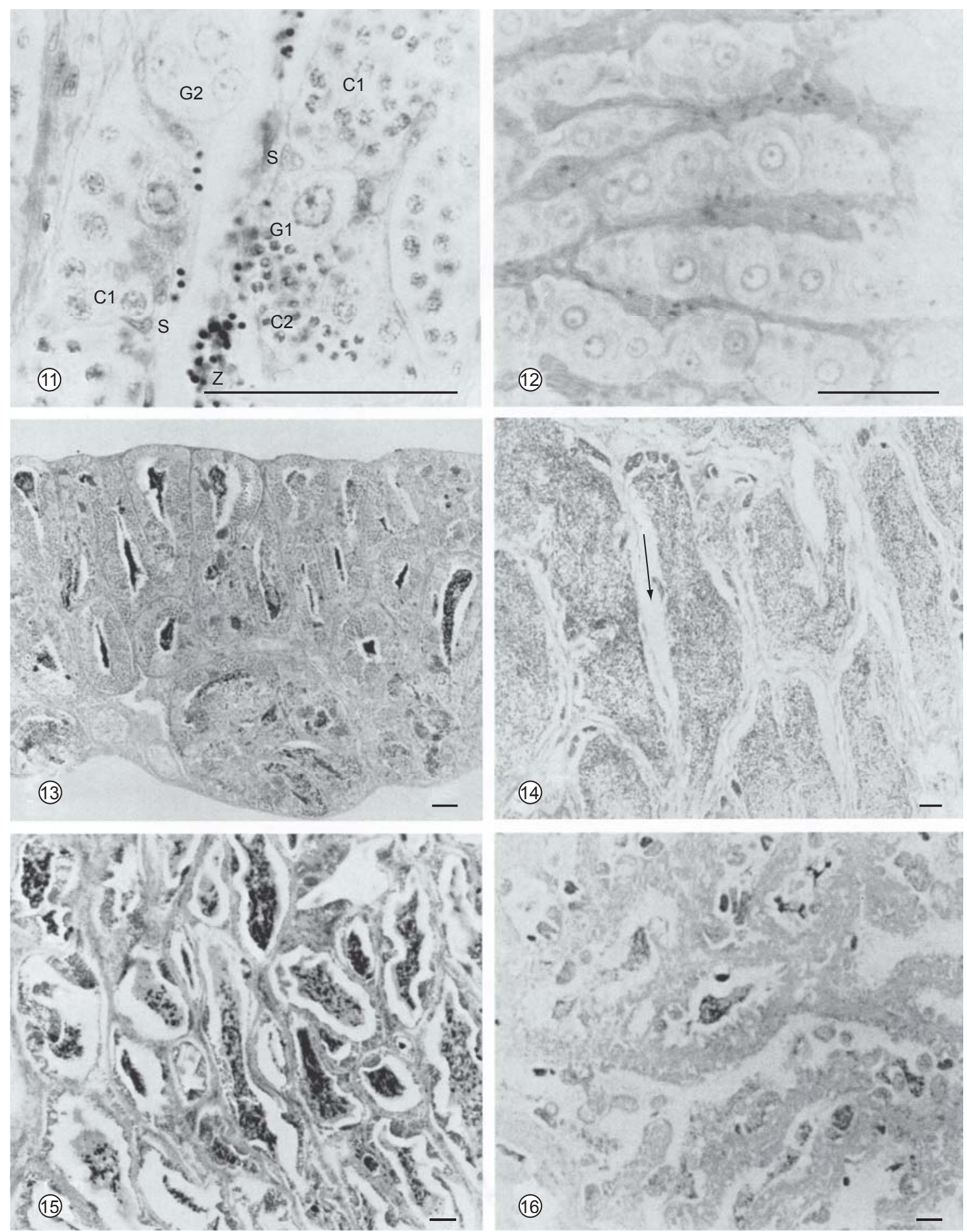

Fig. 11-16 - Testes of $B$. orthotaenia at different stages of maturation: 11) spermatogenic cells; G1 = primary spermatogonia, $\mathrm{G} 2$ = secondary spermatogonia, $\mathrm{C} 1$ = primary spermatocytes, $\mathrm{C} 2=$ secondary spermatocytes, $\mathrm{Z}=$ spermatozoa and $\mathrm{S}=$ Sertoli cells; 12) stage 1 or resting; 13) stage 2 or initial maturation; 14) stage 3 or advanced maturation/mature with acidophyle secretion inside the lumen of seminiferous tubules (arrow); 15) stage 4 or regression with residual spermatozoa and acidophyle secretion inside the lumen of the seminiferous tubules; and 16) stage 4 or spent with lumen of seminiferous tubules with the end of absorption of residual spermatozoa. HE. Scale bars $=50 \mu \mathrm{m}$. 
Females
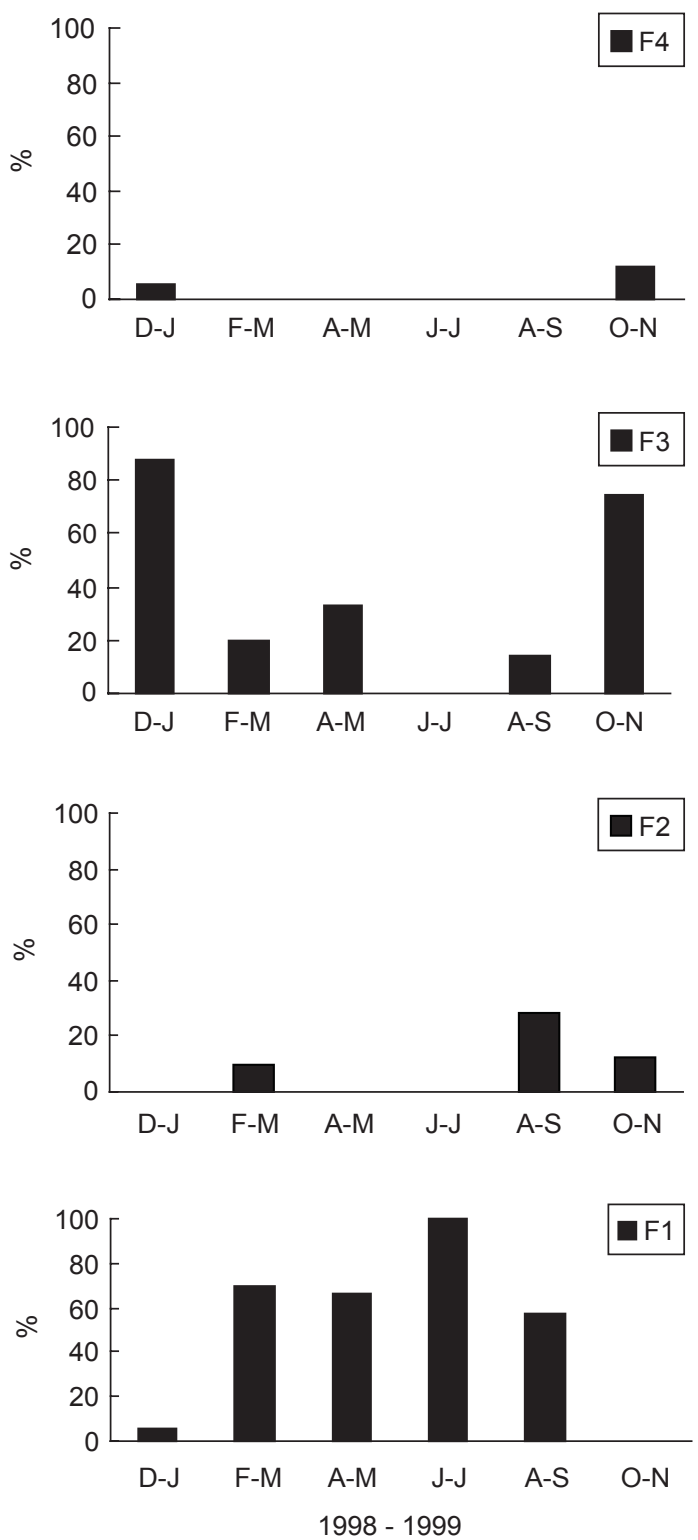

Males
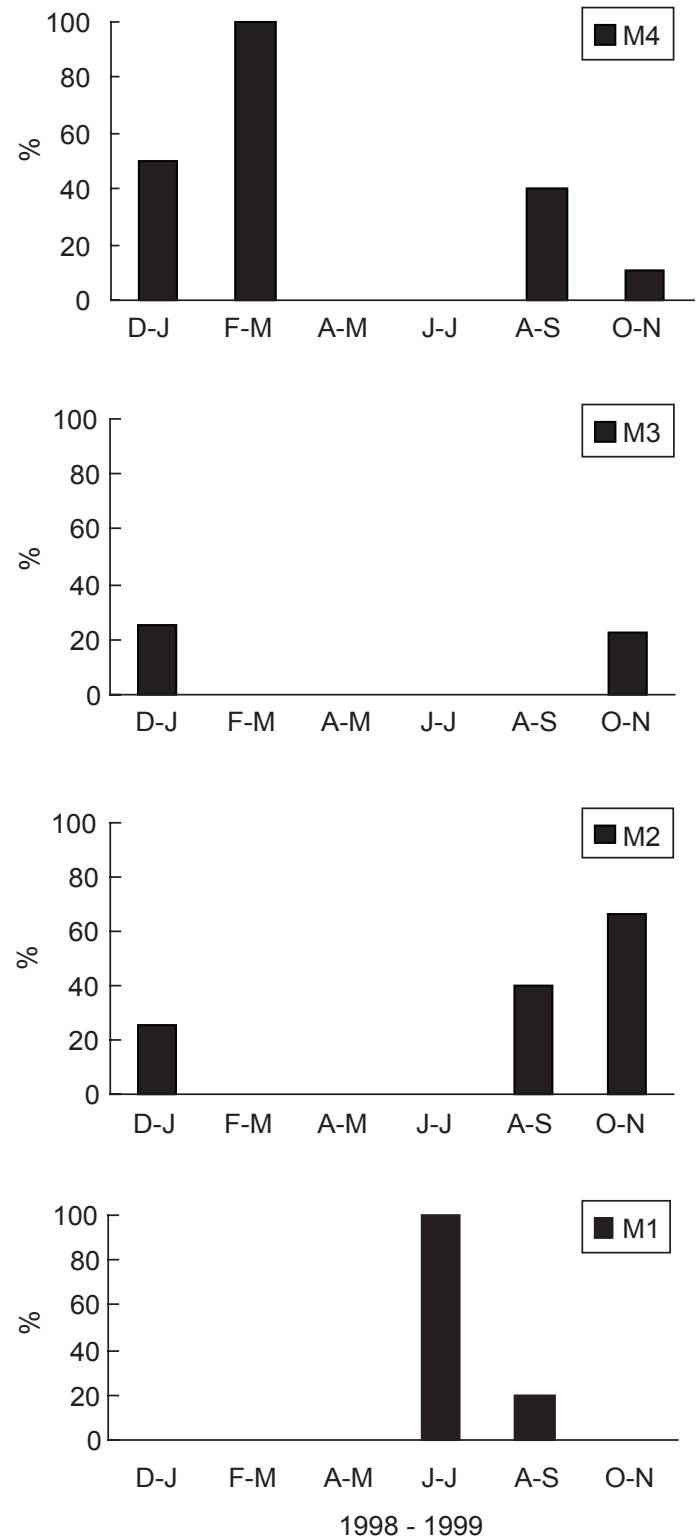

Fig. 17 - Bimonthly distribution of percentage frequency (F\%) of stages of the gonadal maturation of females and males of B. orthotaenia, captured in the São Francisco river, Pirapora region, state of Minas Gerais, between December, 1998 and November, 1999. $\mathrm{F}$ = females, $\mathrm{M}=$ males, 1 = resting, 2 initial maturation, $3=$ advanced maturation/mature, $4=$ regression.

of $B$. orthotaenia during oogenesis, especially in relation to the yolk nucleus, cortical alveoli, zona pellucida and follicular cells, coincide with the findings of Bazzoli (1992) in other fish of the genus Brycon. After spawning, post-ovulatory follicles were formed, which in $B$. orthotaenia, were made up of hypertrophied follicular cells and thin theca, similar to Astyanax bimaculatus lacustris described by Drummond et al. (2000). These authors have also observed programmed cell death or apoptosis during the involution of the follicles. According to Guraya (1986) and as recorded in this study, even though atresic follicles may be formed at any stage of the reproductive cycle and are more frequent 
TABLE 2

Minimum (Min.), maximum (Max.) and mean (Mn.) values of standard length (SL), total length (TL), and body weight (BW) by stage of gonadal maturation (SGM) of males of $B$. orthotaenia captured in the São Franscisco river, between December, 1998 and November, 1999.

\begin{tabular}{|c|c|c|c|c|c|c|c|c|c|c|}
\hline \multirow{2}{*}{ SGM } & \multirow{2}{*}{$\mathbf{n}$} & \multicolumn{3}{|c|}{ SL (cm) } & \multicolumn{3}{c|}{ TL (cm) } & \multicolumn{3}{c|}{ BW (g) } \\
\cline { 3 - 10 } & & Min. & Max. & Mn & Min. & Max. & Mn & Min. & Max. & Mn \\
\hline 1 & 02 & 19.9 & 28.3 & $24.1 \pm 5.9$ & 23.5 & 34.5 & $29.0 \pm 7.8$ & 160 & 600 & $380.0 \pm 311.0$ \\
\hline 2 & 09 & 19.3 & 31.4 & $27.7 \pm 4.6$ & 23.8 & 37.2 & $32.5 \pm 5.2$ & 160 & 760 & $528.4 \pm 225.3$ \\
\hline 3 & 03 & 24.5 & 30.1 & $28.2 \pm 3.2$ & 30.0 & 36.6 & $34.2 \pm 3.6$ & 320 & 680 & $556.7 \pm 205.0$ \\
\hline 4 & 06 & 25.5 & 33.0 & $29.2 \pm 2.8$ & 32.0 & 39.5 & $35.0 \pm 3.3$ & 295 & 900 & $558.0 \pm 220.0$ \\
\hline
\end{tabular}

$\mathrm{n}=$ number of specimens per SGM, 1 = resting, $2=$ initial maturation, $3=$ advanced maturation/mature, $4=$ spent

TABLE 3

Minimum (Min.), maximum (Max.) and mean (Mn.) values of standard length (SL), total length (TL), and body weight (BW) by stage of gonadal maturation (SGM) of females of $B$. orthotaenia captured in the São Franscisco river, between December, 1998 and November, 1999.

\begin{tabular}{|c|c|c|c|c|c|c|c|c|c|c|}
\hline \multirow{2}{*}{ SGM } & \multirow{2}{*}{$\mathbf{n}$} & \multicolumn{3}{|c|}{ SL (cm) } & \multicolumn{3}{c|}{ TL (cm) } & \multicolumn{3}{c|}{ BW (g) } \\
\cline { 3 - 11 } & & Min. & Max. & Mn & Min. & Max. & Mn & Min. & Max. & Mn \\
\hline 1 & 16 & 21.5 & 34.2 & $27.4 \pm 3.1$ & 25.5 & 40.1 & $32.7 \pm 3.6$ & 190 & 900 & $474.7 \pm 182.7$ \\
\hline 2 & 05 & 27.3 & 30.0 & $29.0 \pm 1.2$ & 32.7 & 36.7 & $35.4 \pm 1.8$ & 440 & 670 & $557.0 \pm 102.0$ \\
\hline 3 & 31 & 25.0 & 36.8 & $31.1 \pm 3.2$ & 33.5 & 44.0 & $37.3 \pm 3.9$ & 355 & 1600 & $742.0 \pm 307.0$ \\
\hline 4 & 03 & 33.5 & 38.3 & $35.7 \pm 2.4$ & 40.5 & 43.2 & $41.9 \pm 1.9$ & 780 & 1450 & $1197.0 \pm 395.0$ \\
\hline
\end{tabular}

$\mathrm{n}=$ number of specimens per SGM, $1=$ resting, $2=$ initial maturation, $3=$ advanced maturation/mature, $4=$ regression.

in regression ovaries, non-ovulated vitellogenic oocytes have begun the process of absorption or atresia. The morphological event occurred when atresic follicles of $B$. orthotaenia were being formed and are compatible with the reports from Miranda et al. (1999).

The wall of the seminiferous tubules of B. orthotaenia was made up of cysts of germ cells at different stages of spermatogenesis and in each cyst, delimited by cytoplasmatic elongations of Sertoli cells, germ cells were at the same development stage, a common pattern in most teleosts (Grier, 1981; Lo Nostro et al., 2003). The basic organization of the testes and morphologic characteristics of spermatogenic cells are common to all fish as well as other vertebrates (Billard et al., 1982). The origin of teleost spermatogenic cells is controversial. In the present study, there were indications of the origin of these cells from spermatogonias, due to their presence in the testes in the whole reproductive cycle, which is compatible with Grier (1981). Spermatogenesis of $B$. orthotaenia occurred, inside the cysts, synchronously with the release of spermatozoa into the lumen of seminiferous tubules, a common pattern in fish of the genus Brycon (Zanoboni-Filho \& Resende, 1988; Romagosa et al., 1999; Nogueira, 2000). However, in some Characids, the cysts hatch when in the spermatid stage (Andrade et al., 2001)

Nogueira (2000) using classic histological techniques detected neutral glicoproteins in the acidophyle secretion of the seminiferous tubules of $B$. orthotaenia. This type of secretion was also reported for other Brazilian Characiforms (Bazzoli, 2003), and due to its histological nature it may act as an energy resource to spermatozoa, similar to seminal vesicles found in some Siluriformes groups (Santos et al., 2001).

In this study, four stages of the reproductive cycle were determined, however, in the literature, the number of these stages varied from three to eleven. This disagreement may be due to the methodology used instead of morpho-functional differences of the gametogenesis process, which seems to have a similar development among teleosts (Bazzoli, 2003). 
The reproduction period of fish in the São Francisco river around the city of Pirapora begins in October (Aguirre, 1936). In fact, in this work the peaks of females and males in advanced maturation/ mature and regression females occurred between October and January. Brito \& Bazzoli (2003) studied the reproduction of the surubim, Pseudoplatystoma coruscans, in the same area and confirmed that the reproduction peak also occurs between October and January, when water turbidity (mean $300 \mathrm{ntu}$ ) and pluviometry (mean $100 \mathrm{~mm}$ ) were high.

The present study indicated that the spawning of Brycon orthotaenia was of the total type, which seems to be characteristic among fish of the genus Brycon (Zaniboni-Filho \& Resende, 1988; Romagosa et al., 1999).

With respect to the size of $1^{\text {st }}$ gonadal maturation of B. orthotaenia in the São Francisco river, Pirapora region, state of Minas Gerais, it is important to report the impossibility of using the L-50 method, that establishes the length in which $50 \%$ of the population is adult and $50 \%$ is immature (Vazzoler, 1996), due to the legislation that regulates fishing activity by not allowing the capturing of immature fish. Therefore, in this work the length of gonadal maturation was suggested based on the total length of the smallest regression male and female, similar to the proceedings used by Bazzoli (2003).

Acknowledgments - We wish to thank CNPq/PADCT/CIAMB III (620088/98-2), CNPq (479733/01), FIP/ PUC Minas (99/02P) and FAPEMIG for their financial support; CAPES for the Master's degree scholarship granted; IEF-MG and IBAMA for their technical support; and the fishermen of Pirapora and Buritizeiro, for their help in the field collections, and to Dr. Robert J. Young for the suggestions in the English version.

\section{REFERENCES}

AGUIRRE, A., 1936, A pesca e a caça no Alto São Francisco, Ministério da Agricultura/Divisão de Caça e Pesca, Rio de Janeiro, 28p.

ANDRADE, R. F., BAZZOLI, N., RIZZO, E. \& SATO, Y., 2001, Continuous gametogenesis in the neotropical freshwater teleost, Bryconops affinis (Pisces: Characidae). Tissue \& Cell., 33(5): 524-532.

BAZZOLI, N., 1992, Ovogênese em peixes teleósteos neotropicais de água doce. Tese de Doutorado em Morfologia, ICB, UFMG, Belo Horizonte, 182p.

BAZZOLI, N., 2003, Parâmetros reprodutivos de peixes de interesse comercial na região de Pirapora, pp. 299-314. In: H. P. Godinho e A. L. Godinho (Eds), Águas, peixes e pescas no São Francisco das Minas Gerais, CNPq/PADCT, Editora PUC Minas, Belo Horizonte, MG, 460p.
BILLARD, R., FOSTIER, A., WELL, C. \& BRETON, B., 1982, Endocrine control of spermatogenesis in teleost fish. Can. J. Fish Aquat. Sci., 39: 65-79.

BRITO, M. F. G. \& BAZZOLI, N., 2003, Reproduction of the surubim catfish (Pisces, Pimelodidae) in the São Francisco River, Pirapora Region, Minas Gerais Brazil. Arq. Bras. Med. Vet. Zootec., 55(5): 624-633.

DRUMMOND, C. D., BAZZOLI, N., RIZZO, E. \& SATO, Y., 2000, Postovulatory Follicle: A model for experimental studies of programmed cell death or apoptosis in teleosts. J. Exp. Zool., 287: 176-182.

GODINHO, A. L. \& GODINHO H. P., 2003, Breve visão do São Francisco, pp. 15-24. In: H. P. Godinho \& A. L. Godinho (Eds). Águas, peixes e pescas no São Francisco das Minas Gerais. CNPq/PADCT, Editora PUC Minas, Belo Horizonte, MG, 460p.

GRIER, H. J., 1981, Cellular organization of the testis and spermatogenesis in fishes. Amer. Zool, 21: 345-357.

GURAYA, S. S., 1986, The cell and molecular biology of fish oogenesis. In: H. M. SAUER, (Ed.), Monographs in developmental Biology. Basel, 18: 1-223.

LINS, L. V., MACHADO, A. B. M., COSTA, C. M. R. \& HERMANN, G., 1997, Roteiro metodológico para elaboração de listas de espécies ameaçadas de extinção: contendo a lista oficial de fauna ameaçada de Minas Gerais. Fundação Biodiversitas, Belo Horizonte, 55p.

LO NOSTRO, F. L., GREIR, H., MEIJIDE, F. J., \& GUERRERO, G. A., 2003, Ultrastructure of the testis in Synbrachus marmoratus (Teleostei, Synbranchidae): the germinal compartment. Tissue \& Cell, 35: 121-132.

MIRANDA, A. C. L., BAZZOLI, N., RIZZO, E. \& SATO, Y., 1999, Ovarian follicular atresia in two teleost species: a histological and ultrastructural study. Tissue \& Cell, 31(5): 480-488.

NOBLE, R. L. \& JONES, T. W., 1993, Managing fisheries with regulations, pp. 383-402. In: C.C. Kohler \& W.A. Hubert (Eds) Inland fisheries management in North America. Bethesda: American Fisheries Society, 594p.

NOGUEIRA, B. P., 2000, Ciclo reprodutivo e desenvolvimento larval do matrinxã, Brycon lundii Reinhardt, 1874 (Teleostei, Characidae), do rio São Francisco, Minas Gerais. Dissertação de Mestrado em Zoologia, Programa de Pós-Graduação em Zoologia de Vertebrados - PUCMINAS, Belo Horizonte, 95p.

ROMAGOSA, E., NARAHARA, M. Y., BORELLA, M. I., PEREIRA, S. F. \& FENERICH-VERANI, N., 1999, Ultrastructure of the germ cells in the testis of matrinxã, Brycon cephalus (Teleotei, Characidae). Tissue \& Cell, 31(6): 540-544.

SANTOS, J. E., BAZZOLI, N., RIZZO, E. \& SANTOS, G. B., 2001, Morphofunctional organization of the male reproductive system of the catfish Ilheringichthys labrosus (Lütken, 1874) (Siluriformes: Pimelodidae). Tissue \& Cell, 33(5): 533-540.

SATO, Y. 1999, Reprodução de peixes da bacia do rio São Francisco: indução e caracterização de padrões. Tese de Doutorado em Ecologia e Recursos Naturais, Centro de Ciências Biológicas e da Saúde, UFSCar, São Carlos, 179p. 
VAZZOLER, A. E., 1996, Biologia da reprodução de peixes teleósteos: teoria e prática. EDUEM/SBI/CNPq/ NUUPELIA, Maringá, 169p.
ZANIBONI-FILHO, E. \& RESENDE, E. K., 1988, Anatomia das gônadas, escala de maturidade e tipo de desova do matrinxã, Brycon cephalus (Günther, 1869) (Teleostei: Characidae). Rev Brasil. Biol., 48(4): 833-844. 